\title{
Pharmacological Evidence from Plants of Genus Jacaranda
}

\author{
Mariana Barreto Serra ${ }^{1,2 *}$, Wermerson Assunção Barroso ${ }^{4}$, Flávio Freitas Soares Filho ${ }^{3}$, Selma \\ do Nascimento Silva ${ }^{3}$, Antônio Carlos Romão Borges ${ }^{3}$, Matheus Brandão Campos ${ }^{3}$, Roberta \\ Sabrine Duarte Gondim ${ }^{2}$, Ramon Guimarães Souza ${ }^{6}$, Ademilton Costa Alves ${ }^{5}$, Iracelle Carvalho \\ Abreu $^{3}$ and Marilene Oliveira Rocha Borges ${ }^{3}$
}

${ }^{1}$ Clinical Medicine Department, University of São Paulo, Brazil

${ }^{2}$ Department of Pharmacy, Graduate Program in Health Sciences, Federal University of Maranhão, Campus do Bacanga, Av. Dos Portugueses, s/n, Bacanga, São Luís, MA, 65080-040, Brazil

${ }^{3}$ Physiological Sciences Department, Federal University of Maranhão, Brazil

${ }^{4}$ Department of Biomedicine, CEUMA University (UNICEUMA), Brazil

${ }^{5}$ Department of Pharmacy, CEUMA University (UNICEUMA), Brazil

${ }^{6}$ Amorim II Basic Health Unit, Conjunto Consolata, s/n, Amorim, Zé Doca, MA, 65365-000, Brazil

*Corresponding author: Mariana Barreto Serra. Clinical Medicine Department, University of São Paulo, São Paulo 01246-903,

Brazil

\section{ARTICLE INFO}

Received: 幽 June 23, 2020

Published: 蔧 June 29, 2020

Citation: Mariana Barreto S, Wermeson Assunção B, Flávio Freitas Soares F, Selma do Nascimento S, Iracelle Carvalho A. Pharmacological Evidence from Plants of Genus Jacaranda. Biomed J Sci \& Tech Res 28(4)-2020. BJSTR. MS.ID.004671.
ABSTRACT

Jacaranda, a member of Bignoniaceae family, contains 49 species around the world that are native to Central and South America and the Caribbean. Very few additional data are available on the pharmacological evidences from genus Jacaranda. The following article gives a critical assessment of the literature to date, aims to show that the pharmaceutical potential of this genus has been underestimated, and deserves closer attention.

Keywords: Genus Jararanda; Bigonaceae; Secondary Metabolites; Savanna Biome

\section{Mini Review}

The Bignoniaceae is especially common in the tropics of South America and occurs in habitats consisting of mainly woody trees, shrubs, lianas and, rarely, herbaceous plants. Many woody representatives of Bignoniaceae are well known for their usein the timber industry (e.g. Tabebuia, Cybistax, Paratecoma, Stereospermum, Parmentiera, Jacaranda, Catalpa) or as ornamentals (e.g. Jacaranda, Catalpa, Spathodea) [1]. Bignoniaceae Juss., a dicot family that contains, according to respective taxonomic treatments, 700-800 species grouped in 100-125 genera mainly distributed within tropical floras of the world, with lesser representation in temperate regions $[2,3]$. Chemical constituents recognized in the family are naphthoquinones of the lapachol type, iridoid glucosides, alkaloids, flavones, triterpenes, polyphenols, tannins and seed oils [2,4]. Jacaranda, a member of Bignoniaceae family, contains 49 species around the world that arenative to Central and South America and the Caribbean. The majority of Jacaranda are trees ranging from 1 to 45 meters tall, but they can also be found as shrubs and subshrubs. Genus Jacaranda consists mainly of shrubs and trees with opposite bipinnate leaves; terminal, axillary or cauliflorous, paniculate inflorescence. Fruits are oblong flattened capsules with numerous, winged, hyaline or brownish seeds $[1,5,6]$. Previously have reviewed the ethnobotanical, pharmacological and phytochemical aspects of genus Jacaranda. In this review we intend 
to show an overall aspect of genus Jacaranda, as a continuation to the previous work, which will serve as a source of information for researchers from various species of the genus Jacaranda [1,7].

\section{Species of Genus Jacaranda}

\section{Jacaranda oxyphylla}

Jacaranda Oxyphylla CHAM. is an shrub found in the Brazilian Cerrado, commonly known as "caroba-de-São-Paulo" and used on the popular medicine to treat microbial infections [8-10], Pereira et al., 2016 [8,11] made a phytochemical screening and proved the presence of terpenoids, that are potentially active chemicals substances. In the same study, the plant showed antiedematogenic, antimicrobial and antiacetylcholinesterase activity.

\section{Jacaranda Mimosaefolia or J. Mimosifolia}

Jacaranda mimoseafolia is widely distributed in tropical and subtropical areas of the world, traditionally used to heal wounds, ulcers, as well as astringents and in the treatment of diarrhea and dysentery [12]. Previous phytochemical studies revealed that triterpenes [13], flavonoids, acetosides [14], quinines [15], derived phenylpropanoid [16], Fatty acid and anthocyanins [17] are constituents of J. mimosaefolia. Antimicrobial activity of J. mimosifolia against Bacillus cereus, Escherichia coli, Staphylococcus aureus [12,18] and anticândida has also been described [19]. The other study showed hypotensive activities in rats [20].

\section{Jacaranda Acutifolia}

Jacaranda acutifolia is widely distributed in Central America, where is used as an ornamental tree. It presents in its constitution secondary metabolites of the class of flavonoids [21] and tannins [22]. In 20014, Singab et al., found that the species has antimicrobial activity [22].

\section{Jacaranda Ulei}

Jacaranda ulei Bureau has been popularly used in the treatment of rheumatic diseases, backache, skin disorders, urinary tract disorders and dysentery $[23,24]$. Its constitution is integrated by secondary metabolites of the class of phenolic compounds that can be related to the antioxidant potential of the plant [25], but so far pharmacological studies have not been conducted.

\section{Jacaranda Decurrens}

The specie Jacaranda decurrens CHAM. hasthes cientific synonym Jacaranda pteroides Manso, receiving common names as "carobinha e caroba" [23]. In Brasil, It's na endemic plant of Brazilian cerrado in the states of Goiás, Mato Grosso, Maranhão e São Paulo [26]. It has its leaves used on the treatment of high blood pressure, as a purifying blood, in infectious processes and liver disorders $[27,28]$.

The hydro-alcoholic extract of the leaves of carobinha presented antioxidant activity similar to the rutin standard, revealing to have potential sequestering of $\mathrm{H}+$ cations [29]. It was also demonstrated anti-inflammatory activity in induced model of paw edema in rats, similar to dexamethasone standard [30]. In recent study, our research group observed healing activity of the hydro-alcoholic extract of the species leaves [31]. Study with the hydro-alcoholic extract of plant leaves showed that the triterpene and the ursolic acid have high activities: antimicrobial, antiviral, hepatoprotective, immunoregulatory and inhibitory of human cancer cells [32,33]. However, few pharmacological studies about the plant J. decurrens CHAM. were found on the literature, although phytochemical analysis performed with the specie indicates the presence of flavonoids, flavones, triterpene, oleanolic acid and ursolic acid [34] that can be related with its therapeutic potential.

\section{Jacaranda Puberula}

Jacaranda puberula CHAM., also known as "caroba" and "carobinha" in Brazil, is a midsize tree (4-7 m) native to Brazil, where is largely distributed in the states of Rio de Janeiro and Rio Grande do Sul and Mata Atlântica. There are studies reporting the use of extracts of the leaves of this tree for the treatment of burns $[35,36]$, but has not been found scientific evidences about this.

\section{Jacaranda Caroba (Vell.) A. DC}

Jacaranda caroba is popularlyknown as caroba, caroba muuda, carobinhag, camboatág, camboatá-pequenog, cambotég, carobado-campog, caroba-miúdag, carobado-carrascog [37]. Jacaranda caroba has been traditionally employed as a bitter or astringent, as diuretic and against syphilis, applied externally during baths in the treatment of infectionsand as a catharticremedy. The application of the macerated leaves in alcohol (cachaça) in cicatrization and internal ingestion to treat ulcers is widely practiced $[37,38]$.

The phytochemical assay of the J.caroba detected the presence of iridoids, triterpenes and steroids, as well as coumarins, flavonoids and alkaloids absent. Ursolic acid, a-amyrin and a mixture of ursolic acid and oleanolic were isolated [38,39]. Jacaranda caroba (Vell.) A. DC was analyzed by HPLC-DAD-ESI/MS and revealed the presence of four dicaffeoyl acid derivatives and nine flavonoids including quercetin, kaempferol and isorhamnetin derivatives. Isorhamnetin3-0-rhmanoside-7,4'-di-0-glucoside and quercetin-3-0-(2pentosyl) hexoside were the main metabolites in both the aqueous and hydromethanolic extracts and qualitative and quantitative differences werefound between the extracts. The aqueous extract wasricher in dicaffeoyl acid derivatives [39].

The ethanolic extract of Jacaranda caroba $\left(\mathrm{IC}_{50}\right.$ of $13.22 \mathrm{lg} /$ $\mathrm{mL}$ ) was potent against stationary-phase promastigotes of Leishmania amazonensis [40]. Aqueous and hydromethanol leaves extracts of Jacaranda caroba (Vell.) A. DC proved to be strong radicals' scavengersand effective monoamine-oxidase A inhibitors, butshowed weak protection against cholinesterases activity [39]. Jacaranda caroba (Bignoniaceae) presented strong toxicity to THP1 monocytic cells line [41]. 


\section{Jacaranda Obtusifolia}

Commonly known in Colombia as Gualanday, the Jacaranda obtusifolia can be found in Venezuela as: clavellina montanesa, clavellina, clavellino, guarupa, rabo de iguana, uadam-kayu, sanjose, casabe, uadacamayu, patico; besides Venezuela, Jacaranda is used in Guyana to promote wound healing and in Colombia to treat syphilis[42]. A study described the bioassay-guided isolation, structure elucidation and anticancer evaluation of five flavonoids (-)-liquiritigenin (1), (-)-neoliquiritin (2), isoliquiritigenin (3), isoliquiritin (4) and formononetin (5) from the twigs of Jacaranda obtusifolia H. B. K. ssp. rhombifolia (G. F. W. Meijer) Gentry. The structures were elucidated based on H-1, C-13 NMR, comprehensive 2D NMR, MS analyses and comparison with previously reported spectral data. Compounds 1 and 3 were demonstrated to be inhibitory in vitro against NCI-H187 (small cell lung cancer) with IC50 values of 30.1 and $16.6 \mathrm{mu} \mathrm{g} \mathrm{mL} \mathrm{(-1),} \mathrm{respectively.} \mathrm{The} \mathrm{isolates}$ were non-cytotoxic to Vero cells (African green monkey kidney) [43].

\section{Jacaranda Cuspidifolia}

Consider a medium-size tree with height of 3 to 10 meters, the Jacaranda cuspidifolia Mart. is known as jacarandá, caroba, caiuá, pau-de-colher, pau-santo, carobeira and bolacheira in Brazil. The phytochemistry prospection of the plant extract of Jacaranda cuspidifolia detected the presence of tannins, flavonoids, terpenes, coumarins and steroids [44]. Lupeol, ursolic acid and oleanolic are the principal isolated terpenoids and that present inhibitory growing activity of Micobacterium [42]. This specie presents insecticides properties being used the root for the treatment of scabies. It's a blood purifier and used in bacterial infections as syphilis and gonorrhea. The wood, bark and leaf are used in the fight against the fever [44]. A study investigated in vitro leishmanicidal activity from 16 different Brazilian medicinal plants, between them the ethanolic extract of J. cuspidifolia leaves. Extracts of J. cuspidifolia presented higher selectivity index, with high leishmanicidal activity and low cytotoxicity in the mammalian cells The capacity in treated infected macrophages using the extracts and/or fractions of J. cuspidifolia was also analyzed, and reductions of $97.16 \%$ in the parasite burden, were observed 40 .

\section{Jacaranda Caucana}

J. caucana was first described in 1917 by Pittier. It was found in the Cauca Department of Colombia, hence its name. Further studies by Gentry divided the species into four subspecies: calycina, caucana, glabrata, and sandwithiana. In Panama, only the former has been described [5]. The only phytochemical studies were done by Ogura et al., who reported cytotoxic activities of J. caucana due to the presence of jacaranone, a quinonid compound [45-47]. Were isolated and characterizated some compounds as glycoside and neolignan [48], metabolites known for their antioxidant and radical-scavenging activities [48].

\section{Jacaranda Copaia}

Studies realized in the Amazon describe the popular use of the plant in the treatment of skin infections, through sap application of barks and leaves. Moreover, Indians "Andoque" in the Colombian Amazon prepare a decoction of crushed leaves until a consistency of the honey type to apply topically this medication to promote healing [49]. Another study report popular use of the plant in the treatment of gastrointestinal disorders, diarrhea treatment, leishmaniasis treatment in South America and cancer prevention [50]. There were no pharmacological studies demonstrating the plant action for any of the reported activities.

\section{Conclusion}

Despite the diversity of species that make up the Jacaranda genus, and ethnopharmacological studies highlight the use of parts of these plants for therapeutic purposes, there are still few chemical and pharmacological papers that seek to clarify the secondary metabolites present in the species and their respective biological activities.

\section{Acknowledgment}

We like to express sincere appreciation and deep gratitude to all participants in this work.

\section{Conflict of Interesting}

The authors declare no conflict of interest.

\section{References}

1. María Salomé Gachet, Wolfgang Schühly (2009) Jacaranda-an Ethnopharmacological and Phytochemical Review. Journal of ethnopharmacology 121.

2. Hegnauer R (1964) Chemotaxonomie der Pflanzen | SpringerLink: Birkhäuser Verlag Basel, Basel.

3. Mabberley DJ, Wadham College O (1997) Mabberley's Plant-book: A Portable Dictionary of Plants, their Classification and Uses: Cambridge University Press, London,UK

4. Hegnauer R (1989) Chemotaxonomie der Pflanzen: Birkhäuser Verlag Basel, Basel.

5. Gentry AH (1992) Bignoniaceae: Part II (Tribe Tecomeae). New York: New York Botanical Garden Press on behalf of Organization for Flora Neotropica :1-370.

6. Pennington TD, Reynel C (2004) DA. Illustrated Guide to the Tress of Peru. Sherbone: DH Books.

7. (2014) Nada M Mostafa OAEa ANBS. The Genus Jacaranda (Bignoniaceae): An Updated Review. Pharmacognosy Communications 4

8. VV Pereira, RR Silva, MH Dos Santos, DF Dias, MEC Moreira, et al. (2016) Antioedematogenic Activity, Acetylcholinesterase Inhibition and Antimicrobial Properties of Jacaranda Oxyphylla. Natural product research 30

9. Elza Guimarães , Luiz Claudio di Stasi, Rita de Cassia Sindrônia MaimoniRodella (2008) Pollination biology of Jacaranda oxyphylla with an emphasis on staminode function. Annals of Botany 102: 699-711. 
10. Pereira VV, Duarte LP, Silva RR, Takahashi JA (2016) New jacaranone glucoside from Jacaranda oxyphylla leaves. Natural Product Research 30: 2421-2428.

11. Pereira VV, Silva RR, Duarte LP, Takahashi JA (2016) Chemical Constituents of Jacaranda oxyphylla and their Acetylcholinesterase Inhibitory and Antimicrobial Activities. Records of Natural Products 10: 392-396.

12. Mahran GH, El-Fishawy AM, Hosny AMS, Hilal AM (1991) Phytochemica and antimicrobial study of Jacaranda mimosifolia D. Don grown in Egypt. HerbHung 30: 98-108.

13. Prakash L, Garg G (1980) Chemical examination of the root barks of jacaranda-mimosaefolia d don and tabebuia-pentaphylla (linn) hemsl. Pharmazie 35: 649.

14. Moharram FA, Marzouk MSA (2007) A novel phenylethanoid dimer and flavonoids from Jacaranda mimosaefolia. Zeitschrift Fur Naturforschung Section B-a Journal of Chemical Sciences 62: 1213-1220.

15. Subramanian SS, Nagarajan S, Sulochana N (1973) Hydroquinone from leaves of jacaranda-mimosaefolia. Phytochemistry 12: 220-221.

16. Zaghloul AM, Gohar AA, Ahmad MM, Baraka HN, El-Bassuony AA (2011) Phenylpropanoids from the stem bark of Jacaranda mimosaefolia. Natural Product Research 25: 68-76.

17. Chisholm MJ, Hopkins CY (1962) Isolation and Structure of a New Conjugated Triene Fatty Acid1. JOrgChem 27: 3137-3139.

18. Perezgutierrez RM, Perezgutierrez S, Perezgonzalez C (1994) In-vitro susceptibility of pathogenic acanthamoeba-castellanii to jacarandamimosaefolia extract. Phyton-International Journal of Experimenta Botany 56: 39-41.

19. Lazare Sidjui Sidjui RMTK, Elisabeth Zeuko'o, Olivier Noté (2014) Secondary Metabolites from Jacaranda Mimosifolia and Kigelia Africana (Bignoniaceae) and Their Anticandidal Activity. Records of Natural Products 8: 307-311.

20. Nicasio P, Meckes M (2005) Hypotensive effect of the hydroalcoholic extract from Jacaranda mimosaefolia leaves in rats. Journal of Ethnopharmacology 97: 301-304.

21. Mostafa NM, Ashour ML, Eldahshan OA, Singab ANB (2016) Cytotoxic activity and molecular docking of a novel biflavonoid isolated from Jacaranda acutifolia (Bignoniaceae). Natural Product Research 30: 2093-2100

22. Singab ANB, Mostafa NM, Eldahshan OA, Ashour ML, Wink M (2014) Profile of Volatile Components of Hydrodistilled and Extracted Leaves of Jacaranda acutifolia and their Antimicrobial Activity Against Foodborne Pathogens. Natural Product Communications 9: 1007-1010.

23. Maroni BC, Di Stasi LC, Rodrigues Machado S (2006) Plantas Medicinais do Cerrado de Botucatu.

24. Guarim Neto G, Universidade Federal de Mato Grosso C, Brasil, Morais RGd, Grosso UFdM (2003) Medicinal plants resources in the Cerrado of Mato Grosso State, Brazil: a review. Acta Bot Bras 17: 561-584.

25. Farias KS, Universidade Católica Dom Bosco CG, Brasil, Santos TSN, et al. (2013) Antioxidant properties of species from the Brazilian cerrado by different assays. Rev bras plantas med 15: 520-528.

26. Mauro Claudia PAMS, Silva Celi de Paula, Missima Juliana, Ohnuki Thiana, Rinaldi Renata Benatti (2007) Estudo anatômico das espécies de cerrado Anemopaegma arvense (Vell.) Stellf. ex de Souza (catuaba), Zeyheria montana Mart. (bolsa-de-pastor) e Jacaranda decurrens Chamisso (caroba) - Bignoniaceae. Rev bras farmacogn 17.

27. Prado DS, Oliveira OP, Oliveira TB (2002) Controle de Qualidade e doseamento de açúcares redutores de amostras de Jacaranda decurrens Cham. (carobinha) comercializada na cidade de Goiânia. Faculdade de Farmácia da Universidade Federal de Goiás, Brazil.
28. Zatta DT, Oliveira FNM, Bara MTF (2009) Leaf Morpho-anatomy and Quality Parameters of Jacaranda decurrens (Bignoniaceae). Latin American Journal of Pharmacy 28: 358-365.

29. Carvalho CA LM, Bertoni BW, França SC, Pereira OS, Fachin AL, et al. (2009) Atividade antioxidante de Jacaranda decurrens Cham., Bignoniaceae. Revista Brasileira de Farmacognosia 19: 592-598.

30. Santos JA, Arruda A, Silva MA, Cardoso CA, Maria do Carmo Vieira, et al. (2012) Anti-inflammatory effects and acute toxicity of hydroethanolic extract of Jacaranda decurrens roots in adult male rats. J Ethnopharmacol 144: 802-825.

31. Serra MB, Barroso WA, Rocha C, Pablo GR Furtado, Antônio CR Borges, et al. (2020) Chemical Characterization and Wound Healing Property of Jacaranda decurrens Cham. (Bignoniaceae): An Experimental Study Based on Molecular Mechanisms. Evidence-Based Complementary and Alternative Medicine.

32. Hsu YL, Kuo PL, Lin CC (2004) Proliferative inhibition, cell-cycle dysregulation, and induction of apoptosis by ursolic acid in human nonsmall cell lung cancer A549 cells. Life Sci 75: 2303-2316.

33. Ma CM, Cai SQ Cui JR, Rui-Qing Wang, Peng-Fei Tu, et al. (2005) The cytotoxic activity of ursolic acid derivatives. Eur J Med Che 40: 582-589.

34. De Carvalho CA, Lourenco MV, Bertoni BW, Suzelei C França (2009) Antioxidant activity of Jacaranda decurrens Cham., Bignoniaceae. Revista Brasileira De Farmacognosia-Brazilian Journal of Pharmacognosy 19: 592-598.

35. Martins MBG, Castro AA, Cavalheiro AJ (2008) Anatomical and chemical characterization of Jacaranda puberula (Bignoniacea) leaves present in Mata Atlantica. Revista Brasileira De Farmacognosia-Brazilian Journal of Pharmacognosy 18: 600-607.

36. Dos Santos PML, Japp AS, Lima LG, Schripsema J, Menezes FD, et al. (2010) Antioxidant activity from the leaf extracts of Jacaranda puberula Cham., Bignoniaceae, a Brazilian medicinal plant used for blood depuration. Revista Brasileira De Farmacognosia-Brazilian Journal of Pharmacognosy 20: 147-153.

37. Luiz Claudio Di Stasi CAH (2002) Plantas Medicinais na Amazônia e na Mata Atlântica. 2 ed. Botucatu, São Paulo: UNESP.

38. Braga FC UFMG, Valadares YM, Julio Antonio Lombardi (2003) Estudo fitoquímico de Erythraea centaurium, Jacaranda caroba, Remijia ferruginea e Solanum paniculatum visando identificar marcadores químicos para o fitoterápico Ierobina ${ }^{\circledR}$. Rev bras farmacogn 13: 28-31.

39. Ferreres F, Grosso C, Gil-Izquierdo A, Valentao P, Andrade PB (2013) Phenolic compounds from Jacaranda caroba (Vell.) A. DC.: Approaches to neurodegenerative disorders. Food and Chemical Toxicology 57: 91-98.

40. Tatiana G Ribeiro, Miguel A Chávez-Fumagalli, Diogo G Valadares, Juçara R Franca , Paula S Lage, et al. (2014) Antileishmanial Activity and Cytotoxicity of Brazilian Plants. Experimental parasitology 143.

41. Priscilla RV Campana, Daniel S Mansur, Grasielle S Gusman, Daneel Ferreira, Mauro M Teixeira, et al. (2015) Anti-TNF- $\alpha$ Activity of Brazilian Medicinal Plants and Compounds from Ouratea semiserrata - Campana - 2015 - Phytotherapy Research - Wiley Online Library. Phytotherapy Research 29: 1509-1515.

42. Gachet MS, Schuhly W (2009) Jacaranda-An ethnopharmacological and phytochemical review. Journal of Ethnopharmacology 121: 14-27.

43. Khamsan S, Liawruangrath S, Teerawutkulrag A, Pyne SG, Garson MJ, et al. (2012) The isolation of bioactive flavonoids from Jacaranda obtusifolia H. B. K. ssp rhombifolia (G. F. W. Meijer) Gentry. Acta Pharmaceutica 62: 181-190.

44. Arruda ALA, Universidade Católica Dom Bosco CG, Brasil, Souza DG (2012) Análise fitoquímicae atividade antimicobacteriana de extratos metanólicos de Jacaranda cuspidifolia Mart. (Bignoniaceae). Rev bras plantas med 14: 276-281. 
45. Ogura M, Cordell GA, Farnsworth NR (1975) Triterpene acids of jacaranda-caucana (bignoniaceae). Lloydia-the Journal of Natural Products 38: 539.

46. Ogura M, Cordell GA, Farnsworth NR (1976) Potential anticancer agents .3. Jacaranone, a novel phytoquinoid from jacaranda-caucana. Lloydiathe Journal of Natural Products 39: 255-257.

47. Ogura M, Cordell GA, Farnsworth NR (1977) Potential anticancer agents .4. Constituents of jacaranda-caucana pittier (bignoniaceae). Lloydia-the Journal of Natural Products 40: 157-168.

ISSN: 2574-1241

DOI: 10.26717/BJSTR.2020.28.004671

Mariana Barreto Serra. Biomed J Sci \& Tech Res

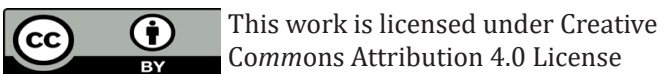

Submission Link: https://biomedres.us/submit-manuscript.php
48. Martin F, Hay AE, Condoretty VRQ (2009) Antioxidant Phenylethanoid Glycosides and a Neolignan from Jacaranda caucana. Journal of Natural Products 72: 852-856.

49. (1989) Correa QJE, Programa de Recursos Vegetales del Convenio Andres Bello (PREVACAB) BCs, Bernal HYM. Especies vegetales promisorias de los paises del Convenio Andres Bello, v. 1-12. In: Guadalupe, ed.: Bogota (Colombia) Secretaria Ejecutiva del Convenio Andres Bello (SECAB).

50. Eliana Rodrigues (2006) Plants and Animals Utilized as Medicines in the Jaú National Park (JNP), Brazilian Amazon. Phytotherapy research: PTR 20.

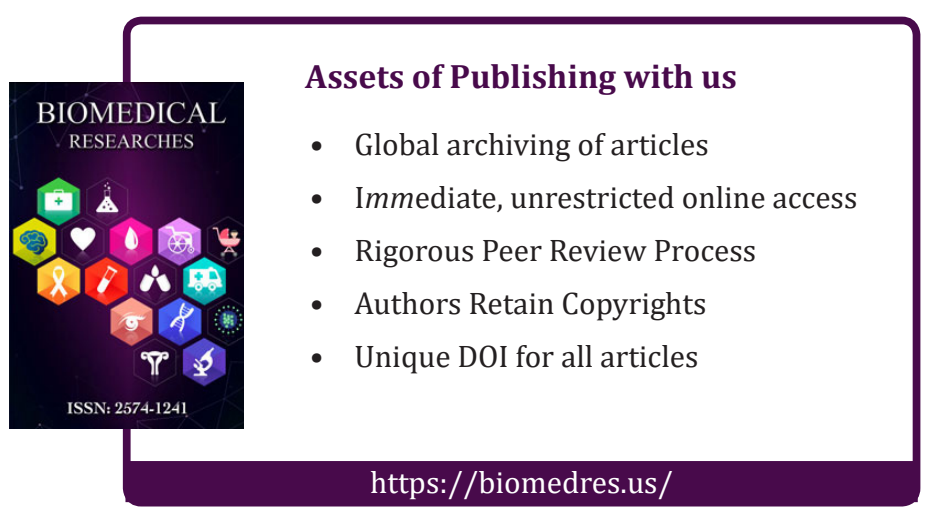

